Lyubov Patrylak ${ }^{1}$, Kazymyr Patrylak $^{1}$, M ykhailo Okhrimenko ${ }^{1}$, Stepan Zubenko ${ }^{1}$, Anton Levterov ${ }^{2}$ and Volodymyr Savytskyi ${ }^{2}$

\title{
COM PARISON OF POWER-ECOLOGICAL CHARACTERISTICS OF DIESEL EN GINE WORK ON MIXED DIESEL FUELS ON THE BASIS OF ETHYL ESTERS OF RAPESEED AND SUNFLOWER OILS
}

\author{
IInstitute of Bioorganic Chemistry and Petrochemistry of National Academy of Sciences of Ukraine \\ 1, M urmans'ka str., 02660 Kyiv, Ukraine; Ikp@ukrpost.net \\ ${ }^{2}$ A.M. Podgorny Institute for M echanical Engineering Problems \\ of National Academy of Sciences of Ukraine \\ 2/ 10, D. Pozharsky str., 61046 Kharkiv, Ukraine
}

Received: May 19, 2014 / Revised: July 07, 2014 / Accepted: N ovember 20, 2014

(C) Patrylyak L., Patrylyak K., Okhrimenko M., Zubenko S., Levterov A., Savytskyi V., 2015

\begin{abstract}
Power-ecological characteristics of diesel engine work on ethyl esters of rapeseed and sunflower oils and their blends with mineral diesel have been studied. Acceptable power and high environmental performance of the engine work on the studied fuels have been established. It is shown that fuels on the basis of sunflower oil are slightly inferior to fuel on the basis of rapeseed oil in energy performance but surpasses them in environmental performance.
\end{abstract}

Keywords: transesterification, ethanol, fatty acid ethyl esters, power characteristics, ecological performance.

\section{Introduction}

One of the most promising alternative energy sources is biodiesel [1-3] - a product of transesterification of triglycerides and low alcohols, the largest producer of which is Germany. As triglycerides mainly the rapeseed oil is used while the alcohol component is methanol obtained from natural gas.

Transition to ethanol would make feedstock basis of the transesterification process fully biologically renewable. However, its use is more energy intensive due to more complex separation of products [4-17].

The work being conducted in IBOCP of NAS of Ukraine [18-21] are aimed at creation of domestic technologies for production of biodiesel fuel on the basis of ethanol and oils of different nature. Sunflower is a traditional oilseed for Ukraine, but recently export of rapeseed has been significantly increases. The question remains open which of these oils priority should be given to for organizing of own biodiesel production.
Therefore, the aim of this study was to compare the power-ecological characteristics of diesel engine work on mixed fuels obtained on the basis of ethyl esters of rapeseed and sunflower oils.

\section{Experimental}

Unrefined rapeseed (ISO 46.072:2003) and sunflower (ISO 4492:2005) oil produced by JSC "Nizhynskyi zhyrkombinat" and rectified ethanol alcohol $(95.6 \%)$ have been used for the synthesis of ethyl esters. Fatty acid composition of oils is given in Table 1 .

Conditions of the homogeneous-catalytic transesterification of rapeseed oil were found earlier [18]: temperature $283-323 \mathrm{~K}$, atmospheric pressure, reaction time 15-60 $\mathrm{min}$, catalyst $(\mathrm{KOH})$ content $1.5-2.0 \mathrm{wt} \%$. For sunflower oil they are similar. Ethanol was dried previously over zeolite $\mathrm{KA}$ to required minimum concentration of $99.0 \mathrm{wt} \%$.

The representative parties (100 kg) of ethyl esters of both oils studied have been synthesized. The main quality parameters are summarized in the Table 2 . The products are marked by narrow fractional composition the main part of them is distilled in the temperature range of 598-605 K for rapeseed and 508-548 K for sunflower ethyl esters, which reflects the homogeneity of the chemical composition of the fuel and indicates the possibility of its use in diesel engines. Up to $623 \mathrm{~K}$ the entire mixture of esters boils away, which fully meets the requirements of the standards for both biodiesel and petroleum fuels. Cetane number of fuels with content of rapeseed oil ethyl esters of 20,40 and $60 \mathrm{vol} \%$ in their 
blends with diesel fuel (cetane number 45) was determined in 10 Chimmotology Center of the Ministry of Defense of Ukraine. It amounted to 45, 47 and 48 units, respectively, which corresponds to 51 cetane number unit for $100 \%$ biodiesel.

Power-ecological characteristics of ethyl esters of fatty acids and their mixtures $(20,40,60,80 \mathrm{vol} \%)$ with mineral diesel fuel was determined by comparative bench testing on two-cylinder diesel engine D21A $(18 \mathrm{~kW}$, $2.1 \mathrm{dm}^{3}, 16.5$ compression ratio). As mineral component higher quality diesel (Euro) type C (ISO 4840:2007) was used.

For each fuel type the series of characteristics have been obtained, including external speed, three load (for $n=$ $=1200,1400$ and $1600 \mathrm{rpm}$ ) and no load characteristics. Effective power of the engine $N_{e}$, torque $M_{k}$, engine efficiency $\eta_{e}$, and fuel consumption $G_{f}$ were selected as power evaluation criteria of engine work. In addition, the content in the exhaust gases of nitrogen oxides $\mathrm{NO}_{\mathrm{x}}$; carbon monoxide $\mathrm{CO}$; carbon dioxide $\mathrm{CO}_{2}$; unburned hydrocarbons $\mathrm{CH}$; and particulate matter $D$ have been determined.

Before the experimental studies of mixed fuel of each composition the optimization of fuel injection timing angle $(\Theta)$ has been performed. Such an optimization allows to reach the maximum possible (for selected fuel mixture) effective power of the engine at a frequency of crankshaft turns $n$ of $1600 \mathrm{rpm}$. The optimum angle $\Theta$ was 22 degrees of crankshaft rotation to top dead center (TDC) for both standard fuel oil and mixed fuels on the basis of rapeseed (sunflower) ethyl esters. This correspondence is explained by identity of cetane number of biofuels (about 51) and diesel fuel of higher quality.

External speed characteristic have been taken at full fuel supply to the engine cylinders, at a frequency of crankshaft turns from $n=1000 \mathrm{rpm}$ to $n=1600 \mathrm{rpm}$ with an interval of $200 \mathrm{rpm}$.

Three load characteristics at frequency of crankshaft turns (for $n=1200,1400,1600 \mathrm{rpm}$ ) have been defined. They have been measured by successive increase in fuel supply within the load changes from zero to a value corresponding to full feed, whereas for the variable option the average effective pressure (engine load) have been taken.

No load characteristics have been fixed at no load engine operation range from $n=1600 \mathrm{rpm}$ to the minimum sustained frequency of crankshaft turns with interval of $200 \mathrm{rpm}$.

This set of characteristics (external speed, three load characteristics and no load characteristic) covers much of the fields of most typical operating conditions of the engine, which allows to obtain reliable integrated environmental performance.

Obtained at engine bench testing experimental characteristics have been brought to the standard atmospheric conditions.

From the results of direct measurements one can determine the following performance of the diesel engine.
Engine power, $\mathrm{kW}$

$$
N_{e}=\frac{M_{k} \cdot n}{9550}
$$

where $M_{k}$ - torque, $\mathrm{N} \cdot \mathrm{m} ; n$ - frequency of crankshaft turns, rpm.

Fuel consumption, $\mathrm{kg} / \mathrm{h}$

$$
G_{f}=\frac{3.6 \cdot B_{d}}{\tau}
$$

where $B_{d}$ - dose fuel expenditure, $\mathrm{g}\left(B_{d}=44.84\right) ; \tau-$ measurement time of fuel consumption, $\mathrm{s}$

Air consumption, $\mathrm{kg} / \mathrm{h}$

$$
G_{\text {air }}=0.0752 \frac{f\left(B_{o}-\Delta p \cdot 9.81 \cdot 10^{-3}\right)}{R_{\text {air }} \cdot T}
$$

where $f$ - frequency meter readings, $\mathrm{Hz} ; B_{o}$ - atmospheric pressure, $\mathrm{kPa} ; \Delta p$ - pressure drop in the inlet air path, $\mathrm{mm}$ WC; $R_{\text {air }}$ - universal gas constant for air, $\mathrm{kJ} /(\mathrm{kg} \cdot \mathrm{K})$ $(R=0.287) ; T$ - temperature before engine inlet, $\mathrm{K}$

The coefficient of air excess

$$
\alpha=\frac{G_{a i r}}{L_{a i r} \cdot G_{f}}
$$

where $L_{a i r}$ - theoretically required amount of air for complete combustion of $1 \mathrm{~kg}$ of mixed fuel, $\mathrm{kg} / \mathrm{kg}$

$$
L_{a m}=\left(L_{a d} \cdot v_{d} \cdot \rho_{d}+L_{a b} \cdot v_{b} \cdot \rho_{b}\right) / \rho m
$$

where $L_{a d}$ - theoretically required amount of air for complete combustion of $1 \mathrm{~kg}$ of mineral diesel fuel, $\mathrm{kg} / \mathrm{kg}$ ( $\left.L_{a d}=14.55\right) ; L_{a b}$ - theoretically required amount of air for complete combustion of $1 \mathrm{~kg}$ of biodisel fuel, $\mathrm{kg} / \mathrm{kg}$ $\left(L_{a b}=12.77\right) ; v_{d}, v_{b}$ - volume fraction of diesel fuel and biofuel in the blended fuel respectively; $\rho_{d}, \rho_{b}, \rho_{m}$ - density of mineral diesel, biodiesel and mixed fuels respectively, $\mathrm{kg} / \mathrm{m}^{3}\left(\rho_{d}=842 ; \rho_{b}=874\right)$

$$
\rho_{m}=v_{d} \cdot \rho_{d}+v_{b} \cdot \rho_{b}
$$

Specific efficient fuel consumption, $\mathrm{g} /(\mathrm{kW} \cdot \mathrm{h})$

$$
g_{e}=\frac{G_{f}}{N_{e}}
$$

Lower combustion heat, $\mathrm{kJ} / \mathrm{kg}$

$$
Q_{l m}=\left(Q_{l d} \cdot v_{d} \cdot \rho_{d}+Q_{l b} \cdot v_{b} \cdot \rho_{b}\right) / \rho_{m}
$$

where $Q_{l m}, Q_{l d}, Q_{l b}$ - lower combustion heat of mixed fuel, diesel fuel and biodiesel, respectively, $\mathrm{kJ} / \mathrm{kg}$ $\left(Q_{l d .}=42500, Q_{l b}=37800\right)$.

Engine efficiency $\left(\eta_{e}\right)$

$$
\eta_{e}=\frac{3.6 \cdot 10^{6}}{g_{e} Q_{l m}}
$$

Average effective pressure, MPa

$$
p_{e}=\frac{30 \cdot N_{e} \cdot \tau_{e}}{i \cdot V_{h} \cdot n}
$$

where $\tau_{e}$ - engine stroke; $i$ - number of cylinders; $V_{h}-$ engine cylinder capacity, 1 .

For engine D21A: $\tau_{e}=4 ; i=2 ; V_{h}=1.041$. 
Table 1

Fatty acid composition of rapeseed and sunflower oils

\begin{tabular}{|c|c|c|c|c|c|c|c|c|c|c|}
\hline \multirow[t]{2}{*}{ Oil } & \multicolumn{10}{|c|}{ Content, wt \% } \\
\hline & $\mathrm{C}_{14}$ & $\mathrm{C}_{16}$ & $\mathrm{C}_{17}$ & $\mathrm{C}_{18: 0}$ & $\mathrm{C}_{18: 1}$ & $\mathrm{C}_{18: 2}$ & $\mathrm{C}_{18: 3}$ & $\mathrm{C}_{20}$ & $\mathrm{C}_{22}$ & $\mathrm{C}_{24}$ \\
\hline Rapeseed & 1.5 & 5.0 & - & - & 87.0 & 2.0 & 0.2 & - & 3.3 & 1.0 \\
\hline Sunflower & 0.2 & 6.7 & 0.3 & - & 40.7 & 44 & - & 7.4 & 0.3 & 0.4 \\
\hline
\end{tabular}

Table 2

Physico-chemical characteristics of ethyl (methyl) esters of fatty acids

\begin{tabular}{|c|c|c|c|c|c|}
\hline Characteristic & $\begin{array}{l}\text { Ethyl esters of } \\
\text { rapeseed oil }\end{array}$ & $\begin{array}{l}\text { Ethyl esters of } \\
\text { sunflower oil }\end{array}$ & $\begin{array}{l}\text { Methyl esters of } \\
\text { rapeseed oil } \\
(\text { EN 14214:2003) }\end{array}$ & $\begin{array}{c}\text { Mineral } \\
\text { diesel } \\
\text { (ISO 386-99) }\end{array}$ & $\begin{array}{c}\text { Improved } \\
\text { mineral diesel } \\
\text { (ISO } \\
4840: 2007) \\
\end{array}$ \\
\hline Density at $20{ }^{\circ} \mathrm{C}, \mathrm{kg} / \mathrm{m}^{3}$ & 877 & 876 & $860-900$ & $840-860$ & $\begin{array}{c}820-845 \\
\text { (at } 288 \mathrm{~K}) \\
\end{array}$ \\
\hline $\begin{array}{l}\text { Kinematic viscosity at } 40^{\circ} \mathrm{C}, \\
\mathrm{mm}^{2} / \mathrm{s}\end{array}$ & 4.74 & 4.43 & $3.5-5.0$ & $\begin{array}{c}1.8-6.0 \\
\text { (at } 293 \mathrm{~K} \text { ) }\end{array}$ & $2.0-4.5$ \\
\hline Cetane number & 51 & $52 *$ & 51 & 45 & 51 \\
\hline $\begin{array}{l}\text { Copper band corrosion ( } 3 \text { hours } \\
\text { at } 50^{\circ} \mathrm{C} \text { ), rating }\end{array}$ & Class 1 & Class 1 & Class 1 & Class 1 & Class 1 \\
\hline Oxidation stability at $110^{\circ} \mathrm{C}, \mathrm{h}$ & 6 & 6 & 6 & - & $<25 \mathrm{~g} / \mathrm{m}^{3}$ \\
\hline Iodine value, $\mathrm{g} \mathrm{J}_{2} / 100 \mathrm{~g}$ & 107 & 99 & $\leq 120$ & 6 & - \\
\hline
\end{tabular}

* Calculated theoretically, based on the data of fractional distillation and using the known empirical dependences for mineral diesel [22-24].

\section{Results and Discussion}

\subsection{Ethyl Esters of Rapeseed Oil}

From the external D21A engine speed characteristics (Fig. 1) one can see that with increasing volume fraction of the biological component $v_{\mathrm{b}}$ in the mixed fuel, a decrease of effective power $N_{e}$ to 6 rel $\%$ and the torque $M_{k}$ to 4 rel $\%$, and increase in fuel consumption $G_{f}$ to 9 rel $\%$ take place. Changes of the first and the second indicators occur due to reduction of power(energy)filling of cylinder because of significantly lower value of combustion heat of mixed fuels compared to the one for standard oil fuel, which is caused by oxygen content in the biofuel. Increasing of the mass fuel consumption $G_{f}$ is caused by higher density of biofuel at volume dosage of fuel injected into the cylinders of a diesel engine.

It is also important that the torque maximum value for engine work on mixed fuel based on rapeseed oil ethyl esters shifted to an area of lower frequency of the crankshaft turns, which positively impacts the vehicle dynamics.

Reducing the efficiency of the combustion process, i.e. the deterioration of the engine efficiency $\eta_{e}$ to 6 rel \% has been observed. However, the deterioration of the engine efficiency is not essential, and for mixed fuels containing biological component 40 and $60 \%$ almost no decrease in efficiency takes place.

Low temperature of combustion of biodiesel-air mixture is also testified by the decrease of nitrogen oxides content in the exhaust gases with increasing proportion of ethyl esters when the engine works at external speed regime (Fig. 2). In the same Figure other environmental parameters of fuels tested are also presented. Thus, with an increase in the proportion of biofuels in the mixed fuel some increase in smoke emissions take place, although with $n$ increasing particulate mater generally decreases. Due to lower carbon content in biofuels than in the mineral ones the reduction of carbon dioxide in the exhaust gases takes place. In turn, reduced emission of carbon monoxide and unburned hydrocarbons testifies to more complete combustion of mixed fuels.

When the engine works under load (Fig. 3) an increase in fuel consumption $G_{f}$ and drop of the effective efficiency $\eta_{e}$ is observed.

Analyzing environmental performance shown in Fig. 4, it can be noted that the increase in $\mathrm{CO}_{2}$ and $\mathrm{NO}_{\mathrm{x}}$ content for low engine load $\left(p_{e}=0-0.4 \mathrm{MPa}\right)$ is in opposite phase to the fall of $\mathrm{CO}$, whereas when $p_{e}>0.5 \mathrm{CO}$ content also increases. There is not dependence of the unburned hydrocarbons content in the exhaust gases in Fig. 4, because they appear only at the maximum load and frequency of crankshaft turns $\mathrm{n}<1200 \mathrm{rpm}$.

For other two crankshaft frequencies (1200 and $1600 \mathrm{rpm}$ ), for which loading characteristics have been recorded, corresponding dependencies are practically the same or similar. 


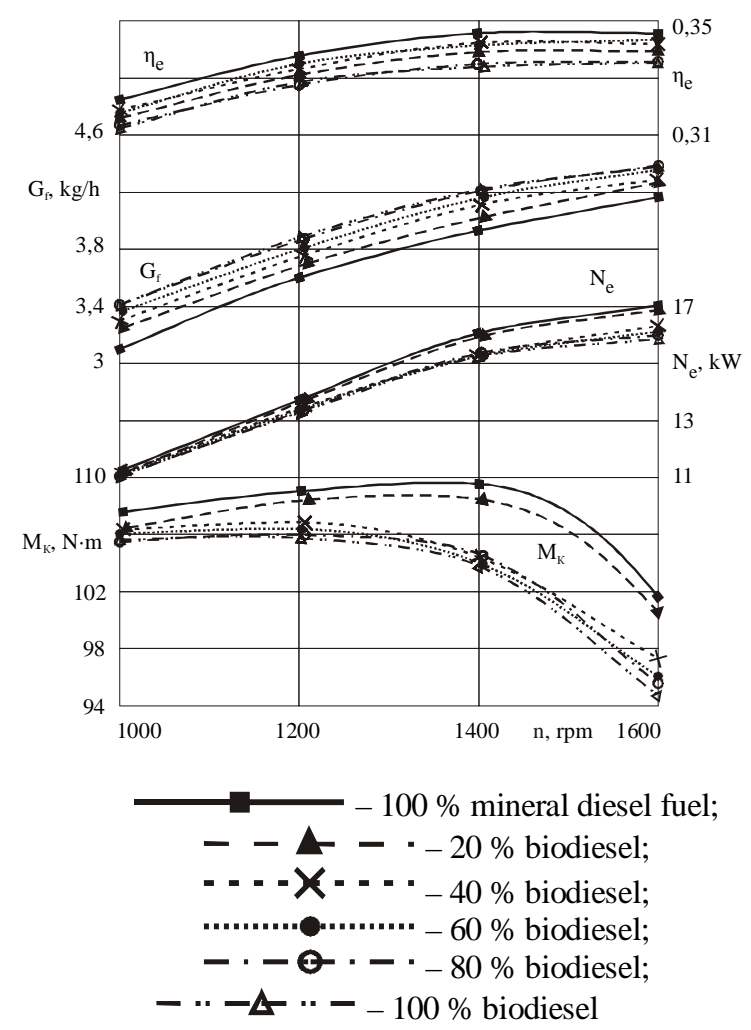

Fig. 1. External speed characteristic of engine work on ethyl esters of rapeseed oil

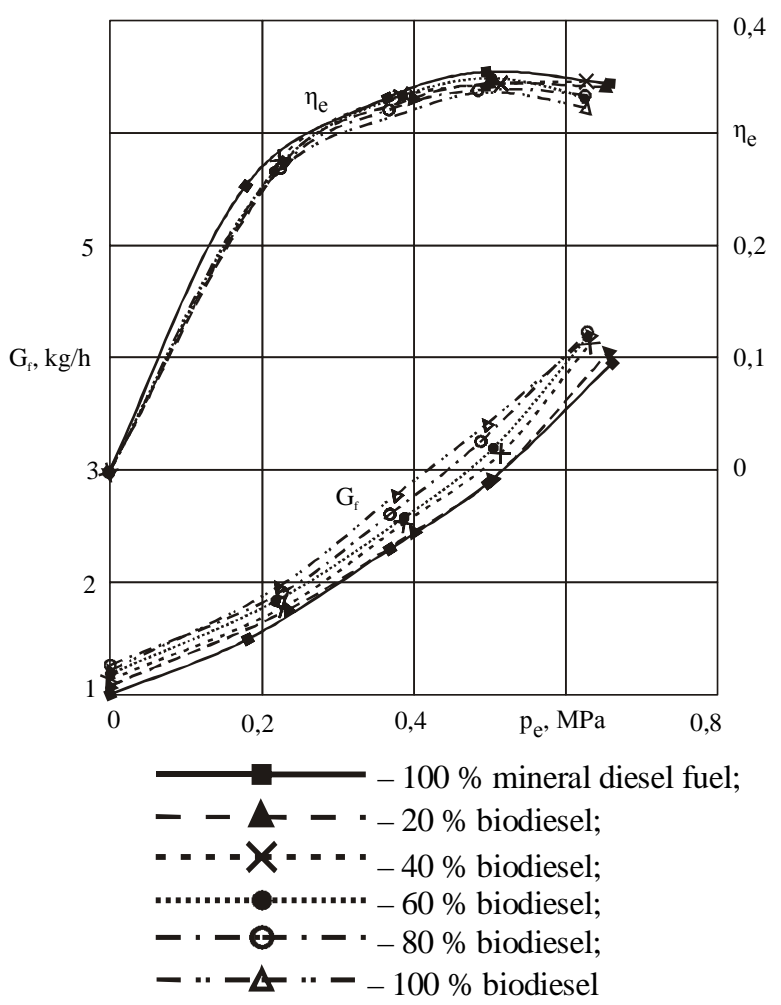

Fig. 3. Load characteristic of engine work $(n=1400 \mathrm{rpm})$ on ethyl esters of rapeseed oil
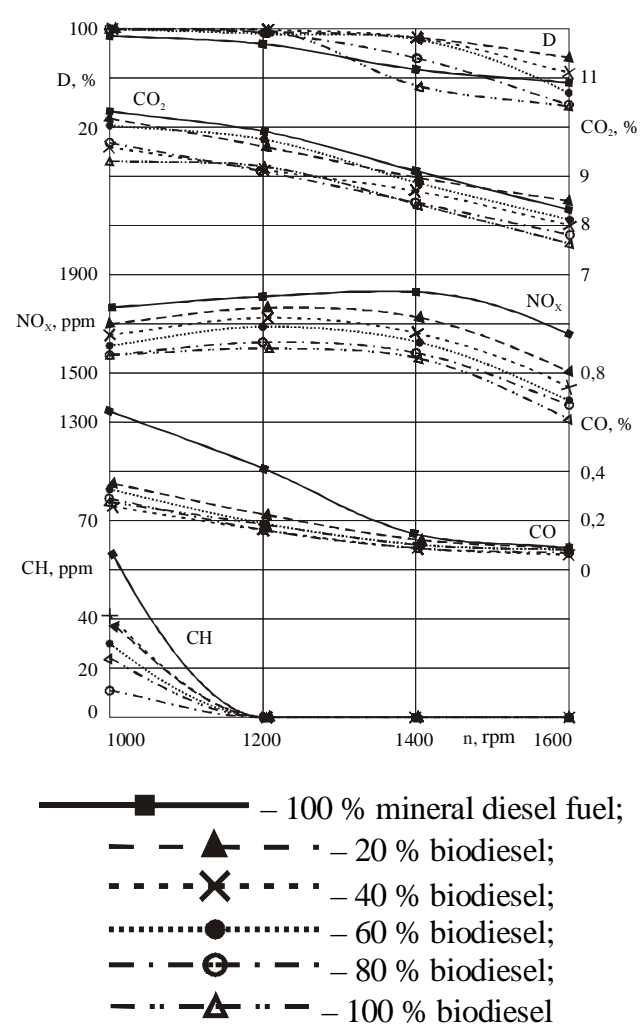

Fig. 2. Ecological performance of engine work at external speed characteristics on ethyl esters of rapeseed oil

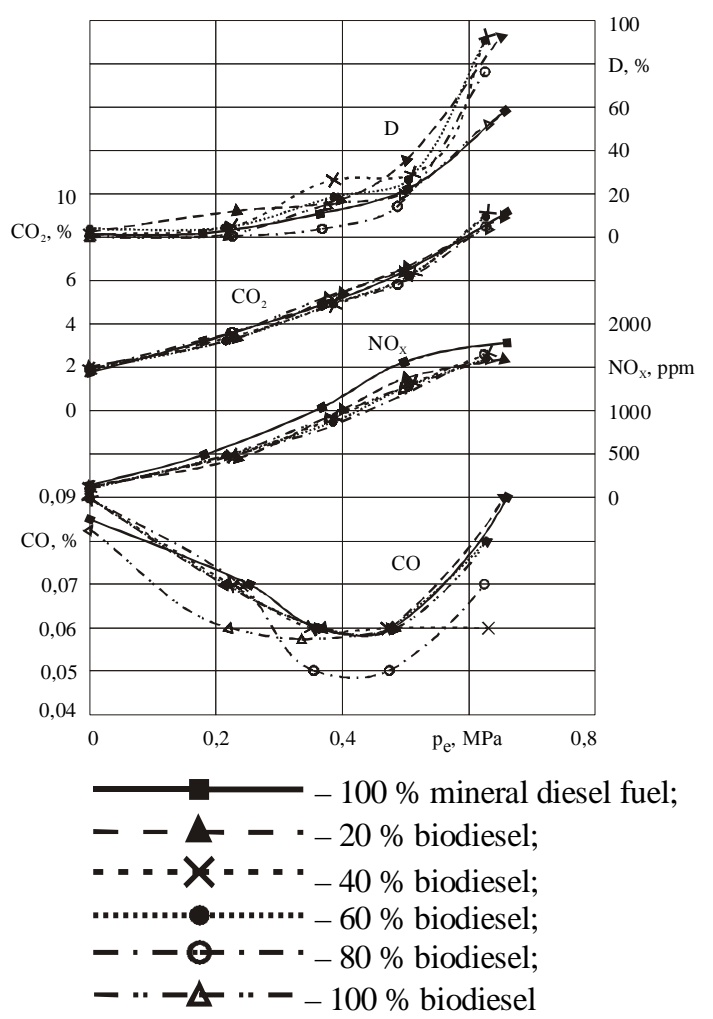

Fig. 4. Ecological performance of engine work on load characteristic $(n=1400 \mathrm{rpm})$ on ethyl esters of rapeseed oil 


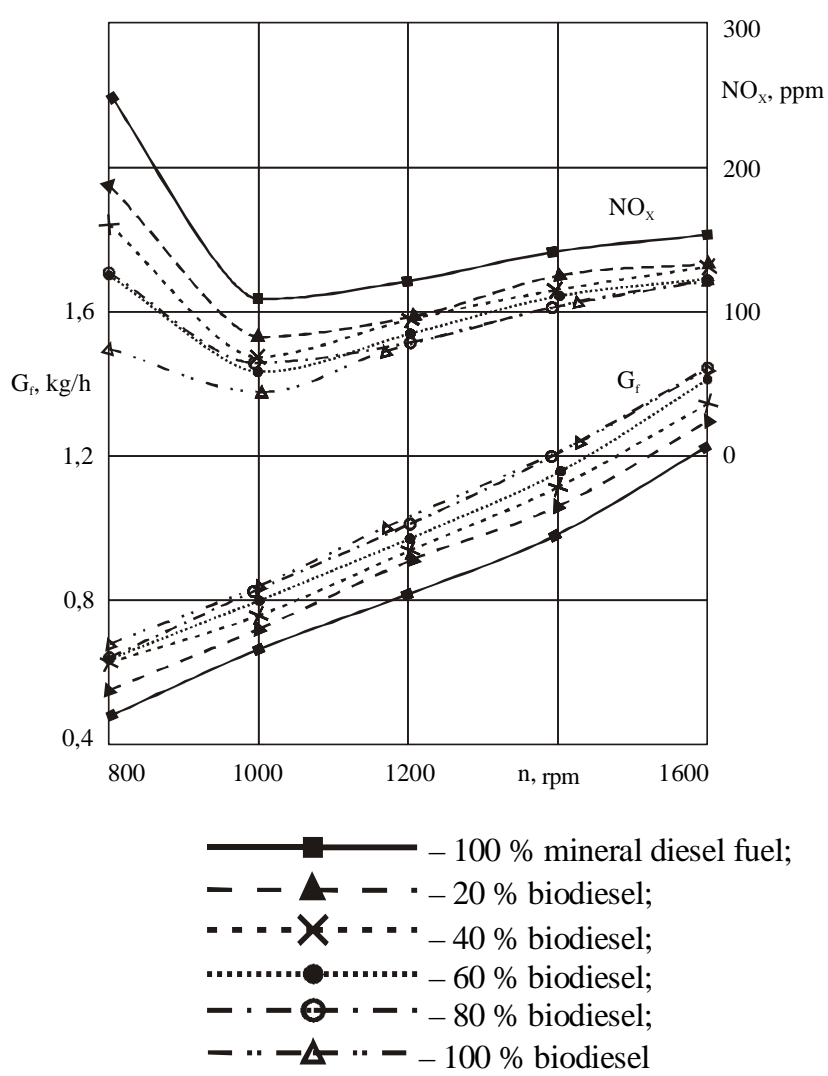

Fig. 5. No load engine characteristics on ethyl esters of rapeseed oil

When the engine works in no load regime (Fig. 5), the patterns of change in fuel consumption $G_{f}$ and nitrogen oxides $\mathrm{NO}_{\mathrm{x}}$ in the exhaust gases with increasing of $v_{b}$ can be explained also by the above reasons. Concerning other components of the exhaust gases for no load engine regime, the emissions of unburned hydrocarbons $(\mathrm{CH})$ for all studied fuels equal zero, and the particulate matter, content of carbon monoxide and dioxide increase with content of biofuels in the mixed fuel vary slightly.

Thus, with increase of the biological component volume part in the mixed fuels the basic performance of the diesel engine work changes rather smoothly, without distinct extremes.

\subsection{Ethyl Esters of Sunflower Oil}

External speed engine test (Fig. 6) for mixed fuels on the basis of ethyl esters of sunflower oil showed that with increase of volume fraction of biofuel $v_{b}$ in the mixed fuel, a decrease of effective power $N_{e}$ up to 8 rel \% and torque $M_{k}$ up to 4 rel $\%$, as well as a rise of fuel consumption $G_{f}$ up to $12 \mathrm{rel} \%$ as well as reduction of engine efficiency $\eta_{e}$ up to $7.5 \mathrm{rel} \%$ for pure $(100 \%)$ biodiesel take place.

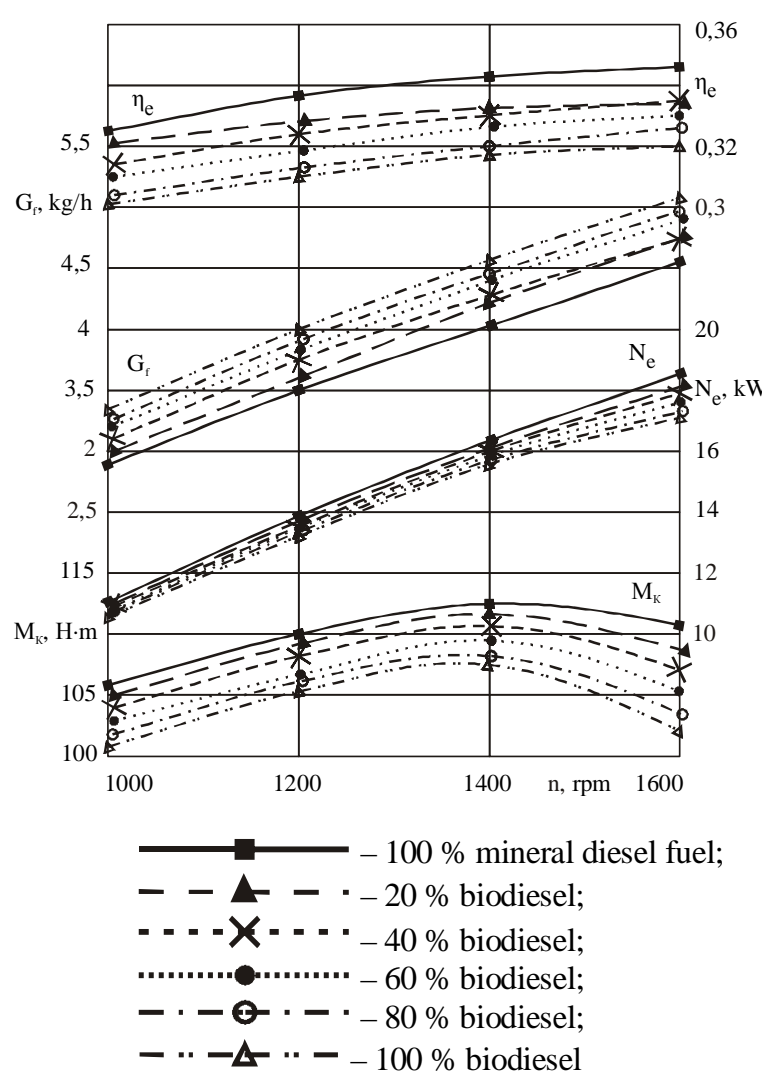

Fig. 6. External speed characteristic of engine work on ethyl esters of sunflower oil

In Fig. 7 environmental performance of the engine is shown. Thus, with increase of content of sunflower esters in the mixture, there is some reduction in particulate matter emissions, besides $100 \%$ biodiesel, for which particulate matter content is higher than the same characteristic for mineral fuel. The decrease of content of nitrogen oxides, carbon monoxide and dioxide in the exhaust gases is observed. CO content is very low in absolute value; therefore it is not essential for the diesel engine. The peculiarity of sunflower esters is the lack of $\mathrm{CH}$ for mixtures with 40, 60 and $80 \%$ biodiesel content.

Decrease of engine efficiency $\eta_{e}$ and increase of $G_{f}$ when the engine works under load characteristics (Fig. 8) is observed.

Fig. 9 presents environmental performance without dependence of the content of unburned hydrocarbons in exhaust gases, because they appear only under maximum load and for petroleum diesel only. Particulate matter, as in the case of external speed performance, is lower than the same obtained for mineral fuel.

When the engine works at no load regime (Fig. 10) with increase of $v_{b}$ the increase of fuel consumption $G_{f}$ and nitrogen oxides $\mathrm{NO}_{\mathrm{x}}$ content in the exhaust gases occurs. The number of the latter pass through a minimum in the frequency range 1000-1200 rpm. 


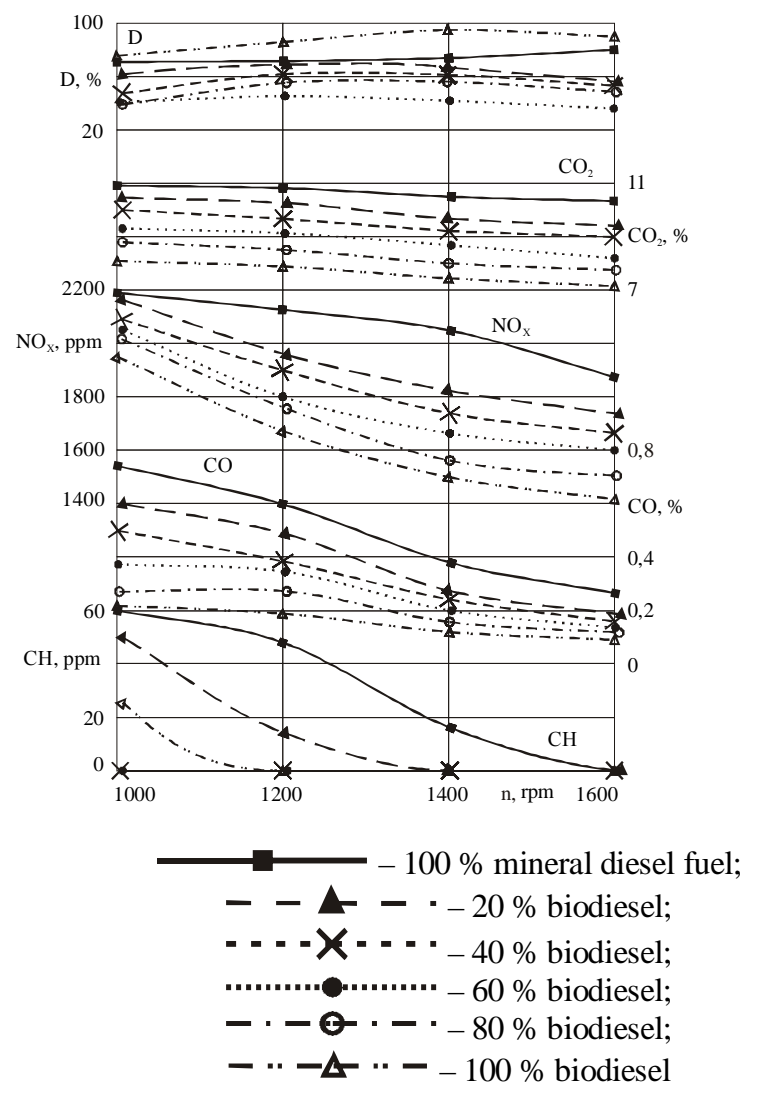

Fig. 7. Ecological performance of engine work at external speed characteristics on ethyl esters of sunflower oil

\subsection{Comparison of Performance of Ethyl Esters of Rapeseed and Sunflower Oils}

The experimental data indicate that the use of mixed fuels on the basis of ethyl esters causes some deterioration of power engine characteristics, i.e. reducing the effective power and torque with the increase of the biofuel volume content in the blend. This reduction is 6 and 4 rel $\%$ for fuels based on ethyl esters of rapeseed oil (Fig. 1) and 8 and 4 rel \% for fuels on the basis of ethyl esters of sunflower oil (Fig. 6).

The reduction of the maximum values of the engine efficiency is also observed (Figs. 1 and 6); the largest difference in the value of the maximum engine efficiency for mineral diesel and mixed fuels is 6/7.5 rel \% (rapeseed/sunflower). According to the $2^{\text {nd }}$ law of thermodynamics, efficiency cannot be $100 \%$. It is known that for diesel engines running on petroleum diesel fuel, it is $30-40 \%$. We have the increase of $\eta_{e}$ value from 0 to $35 \%$ for testing under load and 31-35\% when working at external speed characteristics. In accordance with the ideal Carnot cycle the greater the difference between the temperature of the combustion of fuel in the cylinder and exhaust gas temperature, the greater the efficiency. In the

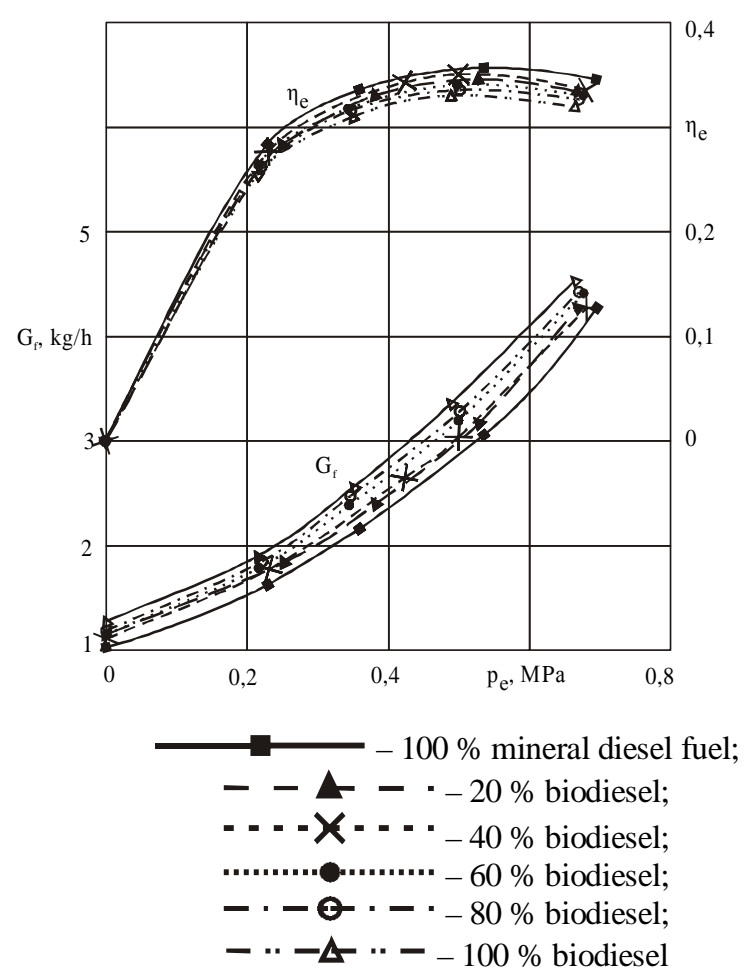

Fig. 8. Load characteristic of engine work $(n=1400 \mathrm{rpm})$ on ethyl esters of sunflower oil

case of biodiesel its combustion temperature is somewhat lower than the temperature of diesel fuel combustion because of oxygen presence in esters molecules, which results in a decrease of mixed fuel efficiency compared with the oil fuel.

However, the reduction of power and economic performance of diesel work using biodiesel fuel compositions is not critical. This applies primarily to fuel mixtures with a low content of a biological component. Thus, for mixed fuels with 20 and $40 \%$ content of ethyl esters is characterized by less than 3 rel $\%$ drop of the nominal effective power, which at operation conditions may remain invisible at all.

The decrease of contents of carbon and nitrogen oxides in exhaust gases while working on the ethyl esters of rapeseed (Fig. 2) and sunflower oils (Fig. 7) is observed, the $\mathrm{NO}_{\mathrm{x}}$ drop is greater for sunflower esters than for rapeseed. So for pure $100 \%$ biodiesel based on sunflower oil it is 20 rel \%, while for fuel based on rapeseed oil - only 15 rel \%. Moreover, the fuels on the basis of sunflower oil show lower particulate matter of the exhaust gases and better combustion efficiency, which may be due to the peculiarities of the fatty acid composition, namely higher content of linoleic acid with 
two unsaturated bonds in sunflower oil. However the peculiarities of fatty acid composition, namely lower hydrogen content in polyunsaturated acids, also cause lower fuel efficiency.

Therefore, the esters of sunflower oil are characterized by $1.5-2$ percentage points higher drop of the effective power and engine efficiency, while at the

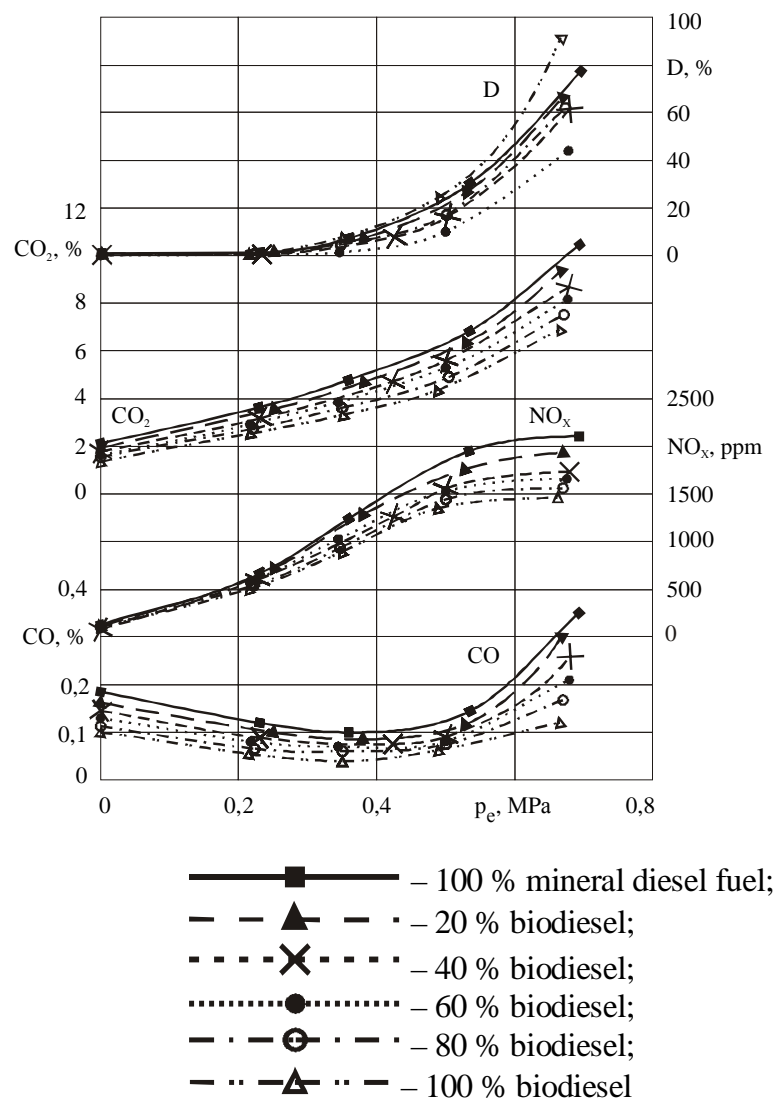

Fig. 9. Ecological performance of engine work on load characteristic $(n=1400 \mathrm{rpm})$ on ethyl esters of sunflower oil

\section{Conclusions}

Bench testing on a diesel tractor engine D21A of ethyl esters of rapeseed and sunflower oils blends with petroleum diesel fuel showed that the obtained fuels are little inferior to mineral diesel fuel of high quality by power-ecology performance.

It is found that some reduction of power and economic performance of the engine using biodiesel fuel compositions is not critical, and in the case of 20-40\% mixtures are almost imperceptible in use.

It is discovered that the optimal fuel injection timing angle into the engine cylinders is the same for standard fuel oil, all mixed fuels, as well as for pure biodiesel, therefore diesel engine can be operated without correction of fuel system settings. same time they have advantages in environmental performance -5 percentage points lower $\mathrm{NO}_{\mathrm{x}}$ emissions and better combustion.

Thus, the use of rapeseed or sunflower oil ethyl esters as raw material for mixed fuels production has own advantages: rapeseed oil gives less power loss while sunflower provides better environmental performance.

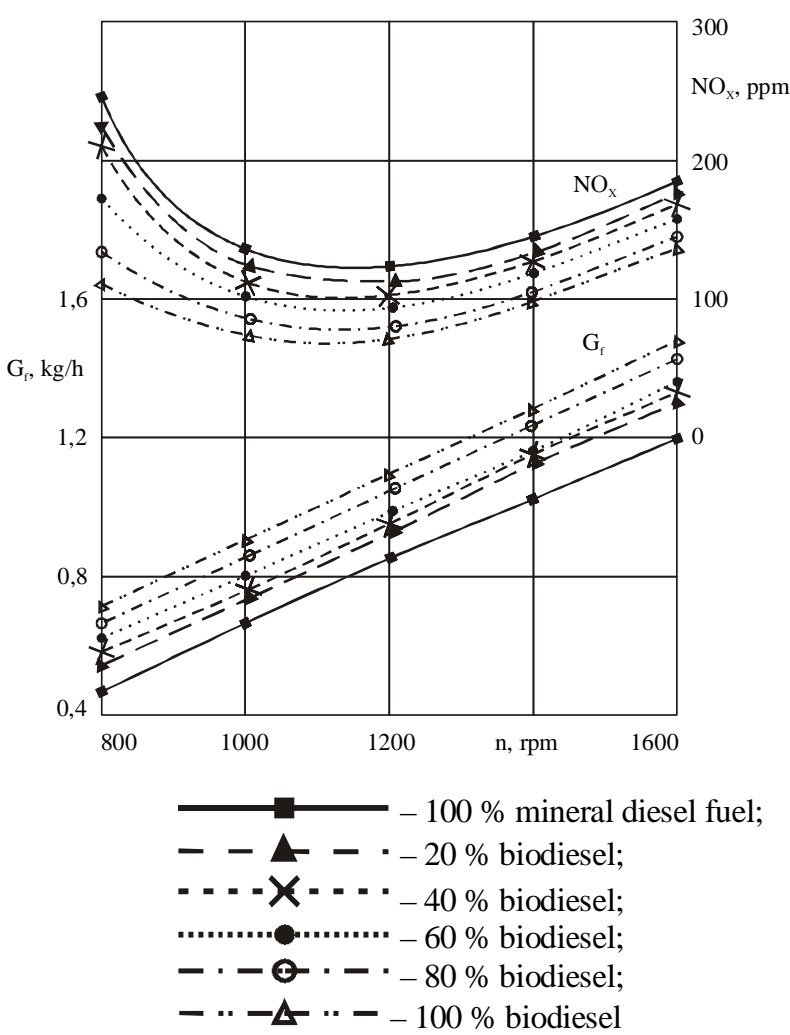

Fig. 10. No load engine characteristics on ethyl esters of sunflower oil

It is observed that the work of diesel engine on the blends of mineral fuel and synthesized ethyl esters is accompanied by a reduction of dioxide and carbon monoxide content as well as nitrogen oxides emission reduction, reaching 15 (20) \% when running on pure esters of rapeseed (sunflower) oils.

It is established that fuels on the basis of ethyl esters of sunflower oil are slightly inferior to fuels on the basis of rapeseed oil esters in energy performance, but surpass them in environmental performance.

\section{References}

[1] Knothe G., Van Gerpen J. and Krahl J.: The Biodiesel Handbook. $2^{\text {nd }}$ edn. AOCS Press, Urbana, Illinois 2005.

[2] Dharma Y., Singh B. and Upadhyay S.: Fuel, 2008, 87, 2355. 
[3] Atabani A., Silitonga A., Badruddin I. et al.: Renew. Sust. Energ. Rev., 2012, 16, 2070.

[4] Stamenkovic O., Velickovic A. and Veljkovic V.: Fuel, 2011, 90, 3141 .

[5] Cernoch M., Skopal F. and Hajek M.: Eur. J. Lipid. Sci. Techn., 2009, 111, 663.

[6] Domingos A., Saad E., Wilhelm H. and Ramos L.: Bioresour. Techn., 2008, 99, 1837.

[7] Anastopoulos G., Zannikov Y., Stournas S. and Kalligeros S.: Energies, 2009, 2, 362.

[8] Cernoch M., Hajek M. and Skopal F.: Bioresour. Techn., 2010, 101, 2071.

[9] da Silva N., Maciel M., Batistella C. and Filho R.: Appl. Biochem. Biotechn., 2006, 129-132, 405.

[10] da Silva N., Batistella C., Filho R. and Maciel M.: Energy Fuels, 2009, 23, 5636.

[11] Cernoch M., Hajek M. and Skopal F.: Bioresour. Techn., 2010, 101, 1213.

[12] Kumar D., Kumar G. and Singh P.: Ultrasonic Sonochem., 2010, 17, 555.

[13] Kucek K., Cesar-Oliveira M., Wilhelm H. and Ramos L.: J. Am. Chem. Soc., 2007, 84, 385.

[14] Menegnetti S., Menegnetti M., Wolf C. et al.: Energy Fuels, 2006, 20, 2262.

[15] Cavalcante K., Penha M., Mendonca K. et al.: Fuel, 2010, 89, 1172.

[16] Suppalakpanya K., Ratanawilai S. and Tongurai C.: Appl. Energy, 2010, 87, 2356.

[17] Issariyakul T., Kulkarni M., Dalai A. and Bakhshi N.: Fuel Process Techn., 2007, 88, 429.

[18] Patrylak L., Kukhar V., Patrylak K. et al.: Pat. Ukr. 88409, Publ. Oct. 12, 2009.

[19] Patrylak L., Patrylak K., Okhrimenko M. et al.: Kataliz i Neftekhim., 2012, 20, 39.
[20] Patrylak L., Patrylak K., Okhrimenko M. et al.: Kataliz i Neftekhim., 2012, 21, 100.

[22] Patrylak L., Patrylak K., Okhrimenko M. et al.: Fuel, 2013, 113, 650

[23] Anisimov I., Badyshtova K., Bnatov S. et al.: [in:] Shkolnikov V. (Ed.), Toplivo, Smazochnye Materialy, Tehnicheskie Zhydkosti. Assortiment i Primenenije. Techinform, Moskwa 1999.

[24] Gureev A., Azev V. and Kamfer G.: Toplivo dlya Diselei. Svoistva i Primenenie. Khimia, Moskwa 1993.

[25] Kuznetsov A. and Kulchev M.: Praktikum po Toplivu i Smazochnym Materialam. Argopromizdat, Moskwa 1987.

\section{ПОРІВНЯННЯ ПОТУЖНІСНО-ЕКОЛОГІЧНИХ ХАРАКТЕРИСТИК РОБОТИ ДИЗЕЛЬНОГО ДВИГУНА НА СУМШШЕВИХ ПАЛИВАХ НА ОСНОВІ ЕТИЛОВИХ ЕСТЕРІВ РІПАКОВОЇ ТА СОНЯШНИКОВОЇ ОЛІЙ}

Анотація. Оцінено енергоекологічні характеристики роботи тракторного дизельного двигуна на етилових естерах ріпакової та соняшникової олій, а також на їх сумішах з мінеральним дизельним паливом. Встановлено прийнятні енергетичні та високі екологічні показники роботи двигуна на досліджуваних паливах. Показано, щуо палива на основі соняшникової олії дещьо поступаються паливам на основі ріпакової олії за енергетичними показниками, але переважають їх за екологічними.

Ключові слова: переестерифікація, спирт етиловий, жирних кислот етилові естери, характеристики потужнісні, показники екологічні. 